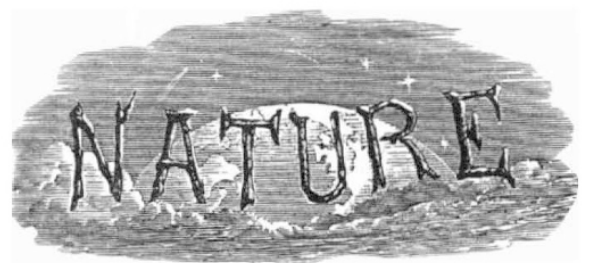

SATURDAY, JUNE I8, I927.

CONTENTS.
Co-operation in Fortstry and Forest
Research Products
An Orthodox View of Witchcraft
Tungsten. By Dr. W. Rosenhain, F.R.S.

Diffraction of Cathode Rays by a Thin Film. Prof. G. P. Thomson and A. Reid . .

British Settlement in the Dominions Overseas. Christopher Turnor; The Writer of the Article Measurement of Evaporation of Sea Water. Prof. Was, Shoulejkin .

Transmission of Heat through a Brick Wall.-Prof.

L. R. Ingersoll and John Bardeen

A New Type of Primary Cell. - D. R. Barber :

The Industrial Revolution. - E. Wyndham Hulme

A Convenient and Rapid Method of Sampling. Chas. E. R. Bruce and W. Bevan Whitney .

The Occurrence of Indium in Tin.-J. R. Green .

Sand-flies and Kala-azar.-Major H. E. Short, I. M.S. .

Early Suggestion as to the Vacum Flask. - Richard Inwards

The Hythe Skulls.-Prof. F. G. Parsons :

The Beginnings and the Early Spread of Agriculture. By Harold J. E. Peake

Television. By Prof $E$ Taylor Jone

Thevision. By Prof. E. Taylor Jones . • • 896

RAILWAY ARRANGEMENTS $. \quad . \quad . \quad . \quad$.

Obituary

News and Views

Our Astronomical Column

Research Items

Foot-and-Mouth Disease

Recent Studies of Skilled Performances, with Reference to the Transfer of Training. By Prof. T. H. Pear

University and Educational, Intelligence

Calendar of Discovery and Invention

Societies and Academies

Official Publications Received

Diary of Societies.

SuPPLEMENT.

The Prediction of Eclipses. By Dr. L J. Comrie .

The Recurrence of Solar Eclipses. By Dr. J. Jackson

Future Total Solar Eclipses in the British Isles By Dr. A. C. D. Crommelin

Meteorological Conditions in Relation to Eclipse Observations. By R. Corless . . . .

Naked-Eye Observations of an Eclipse of the Sun. By Annie S. D. Maunder

Eclipse Photography. By C. P. Butler . .

Radio Telegraphy and the Eclipse of the Sun. By O. F, B.

Astrophysical Éclipse Problems. By Prof. H. Dingle

Spectroscopic Observations during a Partial Eclipse

of the Sun. By Prof. A. Fowler, F.R.S.

The Forms of the Solar Corona and their Origin. liy Dr. William J. S. Lockyer

The Moon's Shadow in Relation to the Earth on June 29. By Dr. E. H. Rayner . . . Astronomical Programmes of Eclipse Work. By F. J. M. Stratton

Observing Parties and Stations

No. 3007, VoL. 119]

\section{Co-operation in Forestry and Forest Products Research.}

CONSIDERING the importance of wood and its by-products in the necessities of life, it is strange how comparatively little systematic action has been taken in England to study the constitution of wood-substance and the structure and properties of the different timbers in relation to their uses. Much of our knowledge, whether it be of the chemistry of wood or its mechanical and physical behaviour, is empirical.

Most of the difficulties encountered in connexion with timber are due to its extraordinary lack of uniformity. When anything goes wrong, as, for example, when an aeroplane strut breaks without warning, the first question always asked is: 'Is this a normal piece of wood ?' A piece of wood may be regarded as normal or abnormal from several different points of view ; for example, in its behaviour under mechanical stress, in either its minute or gross structure, with respect to its treatment during seasoning, or as representing normal growing conditions. The interrelation of these aspects is of very great importance. A timber is usually judged in practice by its mechanical properties, but until our knowledge of the connexion between structure, growth, seasoning, and strength is increased, it will remain impossible to assess the mechanical properties of a piece of timber with any degree of certainty otherwise than by actually breaking a test stick. Further, will the growing conditions which the forester aims at as ideal, produce timber which gives the best results under mechanical tests?

One can only hope to solve such problems by the close collaboration of a number of specialists in different branches of research. The establishment, under the Department of Scientific and Industrial Research, of the Forest Products Research Laboratory at Princes Risborough, within sixteen miles of the Imperial Forestry Institute at Oxford, has opened up a prospect of such collaboration which both institutions have been quick to grasp. These two institutions together provide the much-needed link between the sylviculturist on one hand and the wood-user on the other, harnessing science to the task of informing the sylviculturist of the species to plant, the quality of timber desired, and the means of obtaining it, and the wood-user of the right timber for the several uses, based on mechanical and physical properties, with the best method of preparing it for use.

In this work the Imperial Forestry Institute is primarily concerned with the living tree, from 
the germination of the seed to the felling of the tree for timber: from this point the problems are proper to the Forest Products Research Laboratory, which is concerned with mechanical strength, seasoning, preservation, and manufacture of the timber, and with the investigation of by-products. There exists, however, a common ground, more especially in wood technology, mycology, and entomology. In these three subjects, in order to secure the closest co-operation, the staffs of the two institutions have been practically combined to form a joint section, working on a joint programme, the Forest Products staff being housed at the Imperial Forestry Institute at Oxford.

In dealing with complex problems, it has thus been possible to co-ordinate very different aspects, and the personal contact between the two staffs greatly facilitates the dissemination of information and ideas. For example, a number of independent lines of research, which are being undertaken, have been so arranged that their results may form the basis of an investigation into the problem of 'brashness,' which means an unexpected brittleness in a wood which is not normally brittle; this is a problem of particular importance in aeroplane construction. Other problems coming within this system of co-operative research are the relation between anatomical variation, mechanical strength, and growing conditions; the range of variation consistent with normal mechanical strength; the physical and chemical factors involved in the process of seasoning; the effect of different degrees of fungal attack and the possible relation between insect and fungal attack. In the chemistry of wood-substance, a beginning has been made by arranging for work to be carried out under Sir James Trvine at the University of St. Andrews. This will be closely co-ordinated with the physicochemical research included in the joint programme of the Laboratory and the Imperial Forestry Institute, especially in its relation to shrinking and swelling.

The problems connected with colonial timbers also can only be effectively solved by a combined investigation in which both the growing of the timber and its utilisation are fully considered. Here the co-operation of the systematist and the wood technologist forms an indispensable link, and is very strong under the existing arrangements. Such a combined scheme has already been put forward, in a joint pamphlet which has been circulated to the Forest Services of those parts of the British Empire which do not yet possess facilities to undertake the work themselves.

\section{An Orthodox View of Witchcraft.}

The History of Witchcraft and Demonology. By Montague Summers. (The History of Civilisation Series.) Pp. $\mathrm{xv}+353+8$ plates. (London : Kegan Paul and Co., Ltd. ; New York: Alfred A. Knopf, 1926.) 12s. $6 d$. net.

$A^{N Y}$ anthropologist into whose hands this book A. may come will rub his eyes to find himself translated to an atmosphere of theological controversy which might well be that of the seventeenth century. Indeed, he may even go further and ask why a series entitled "L'Evolution de l'Humanité," or, in translation, "A History of Civilisation," in which an impersonally objective treatment of its subject matter might reasonably be expected, should include a book so subjective in outlook as Dr. Summers" "History of Witchcraft and Demonology." It is surely not the function of the student of the development of thought and belief to inquire into the truth or validity of the tenets he examines, or to obtrude his own beliefs ; his interest lies in the process of development and its product; he may legitimately be expected to regard them as objective matters of fact, the truth or falsity of their content being irrelevant to his purpose.

Dr. Summers, however, believes in witches, and accepts the witcheraft belief as set forth in contemporary or nearly contemporary accounts and in the reports of witeh trials as in the main a true record of a real cult and an actual manifestation of the principle of evil. He believes in the possible efficacy of a malediction. It is true that he acknowledges that the leader of the witches' coven was often proved to be a man-Francis Bothwell, for example, for political and other reasons was suspected of inspiring the Berwick witches who were accused of plotting against James I., and the suspicion is made almost a certainty by his notorious reputation as a 'witch master' when afterwards living at Naples-but he says :

"When God's Ape the Demon can work so successfully and obtain not merely devoted adherents but fervent worshippers by human agency, there is plainly no need for him to manifest himself in person either to particular individuals or at the Sabbats, but none the less that he can do so, and has done so, is certain, since such is the sense of the Church, and there are many striking cases in the records and trials which are to be explained in no other way."

It is therefore with scarcely a feeling of surprise that we read: "anthropology alone offers no explanation of witchcraft. Only the trained theologian can adequately treat the subject." In the 